\title{
The Future Is Here, But the Future Is Not Now \\ (Or in Short, a Review of That Film That Made You Quote Lovelorn Quips This Love Month. Or Earlier If You Caught This in Its Festival Inception.)
}

\section{Libay Linsangan Cantor}

\author{
Takilya ni Leaflens
}

\section{That Thing Called Tadhana (2014)}

Director \& scriptwriter: Tonet Jadaone

Director of Photography: Sasha Palomares

Sound: Jedd/Bryan Dumaguina

Cast: Angelica Panganiban, JM De Guzman

Pitch: Great concept. Fresh take on storytelling. More stories like these, please.

Catch: A good story should be realized by good directing. Pulso is the key. Find your original. Leave duplicates at home. Just saying.

That local movie that got people buzzing again is a good one (Fig. 1). This is good news for the new darlings of Philippine cinema, and I am quite glad that I've had the privilege of peeking at the early stages of these darlings' lives back when they were film students and I their film thesis adviser/film teacher. Teaching back then, I have always reminded these kids that they are going to be the future of Philippine cinema if they so choose to accept that path. After all, they are there in our classroom learning about the art and the craft of this form we so love. As a teacher, I am realistic: I know that some of them are just there for the four-year clocktime course while some are there to gain knowledge and move on to other fields, leaving a handful who will actively pursue different aspects of filmmaking in their lives, be it in the 


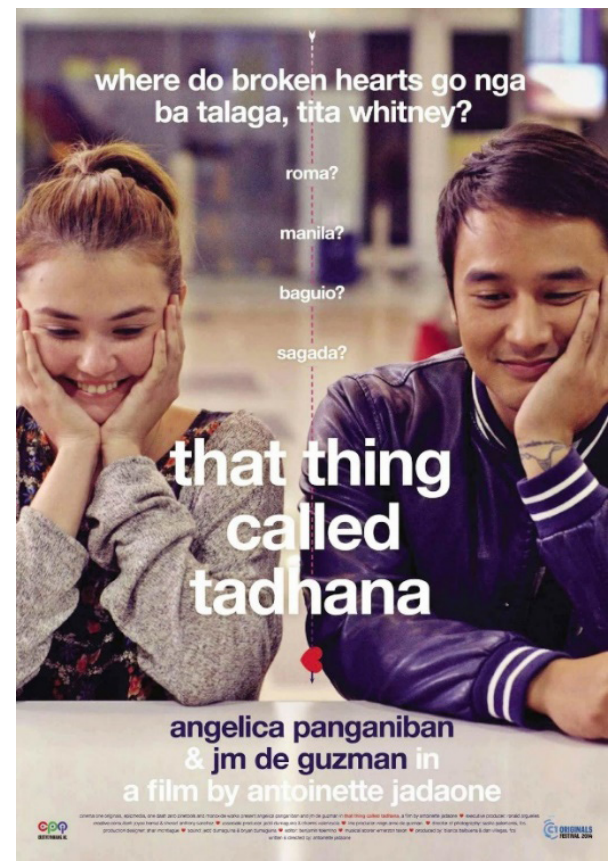

Fig. 1. That Thing Called Tadhana layout/ poster. (Cinema One Originals, Epicmedia, Monoxide Works, and One Dash Zero Cinetools, 2014)

mainstream, the alternative, or the indie. And if they so choose to be part of the film future, then they better prepare for it in the present by looking into the past. For we are only doomed to repeat the mistakes of history when we don't really learn from it. Tama po ba, Sir Teodoro Agoncillo?' But I digress.

The year 2014 was a literary one for this film reviewer and I did not have the time to peek into what is happening in cinemas both local and foreign since I chose to focus on the literary world of my huge universe. That at lumablayp muna lola mo hehe, kaya you know. ${ }^{2}$ So I kinda missed Direk Tonet's other efforts, but I've been hearing some buzz about a couple of works she's done in the past. Alas, since indie filmfest skeds conflicted with my work skeds, I missed all screenings of all things. So I was really glad 
this Cinema One entry had a commercial release, of course picked up by Star Cinema and supported by the same people who were in that ABS-CBN-led indie filmfest. Of course, this might also mean that the same "story consultants" that sat on panels to review scripts/films already shot were also present in this film to give it a few-pointers. Well, you get the drift.

Like what I mentioned in my pitch, the one thing that this film has is a really great concept. And I bet the concept also had a good script that went with it. The thing with Tonet is that she was able to capture the essence of today's Pinay who undergoes real shitty hindi-ito-pang-romcom-nampotah type of love stories, and heartbreaks. Like I've never been so pleased to see a pretty heartbroken girl say Putangina! or Tangina naman! na pagkalutong-lutong mas malutong pa siya sa Lapid's Chicharon pare, all because her heart is hurting. Totoong ganito ang tao kapag heartbroken at totoong masakit kaya totoong napapamura ka at totoong wala kang class, finesse, o anumang kagalang-galang sa hitsura o pagkatao mo minsan kapag brokenhearted ka tangina tulo-uhog habang hagulgol and all. Angelica's performance of the brokenhearted Pinay was well-captured here, great performance talaga si ati. Ever since I saw a different side of her naman as a non-sitcom type of comedian in Here Comes the Bride, pak na pak talaga ang acting ni ati. ${ }^{3}$ That's why I got doubly curious to see this film when I saw her topbill it.

But then here comes JM, once the darling of our business unit sa dos when I was there in my recent past as part of a team conceptualizing teleseryes and helping out in reality shows. I do not know if it was the way he interpreted the character or if he still had some remnants of his personal troubles that crept into his professional performance, but his acting really appeared so uninspired. As in hindi siya mukhang inspired to shoot, much less to work. But I think this meh mode niya worked to build the character of the meek dude that will contrast with the loud gal character of the film. Kaya lang sana minsan naman, sana in-injection-an nila siya ng caffeine sa katawan man lang, know what I am saying. Or maybe I am just nitpicking. Kape pa more! ${ }^{4}$

I felt like some scenes showing the boylet's characters were axed, therefore reducing his performance into a dedma type of guy that ended up not 
being realistic. Like towards the end, when he mentioned that he mentioned about a person taking care of him with Biogesic or something, I was like "Nasaan 'yung eksenang 'yun?" ganun. Weird limbo scenes pare. ${ }^{5}$

The concept of the film is not entirely new. It is the usual tossed salad of a formula wherein you throw in elements already familiar to viewers and cook them up to serve something hopefully familiar but also new. As I have always said in my scriptwriting classes, you cannot reinvent the wheel but by golly push that wheel into a different direction so we could see new scenery and take us to places only you could see from your unique perspective. And literally, this film took us there: to places where we experience heartache so devastating that we tend to forget who we are or where we come from or, more important, where we are going now, now that the love is gone, 'ika nga ng kanta diyan somewhere. Not new because we have already seen films na strangers on a train/bus/plane/what-have-you ang peg, and of course my generation-and theirs-had Richard Linklater's Before series as a default peg. But what's great about Before Sunrise is that the long train ride produced a chance encounter of a boy and a girl who had a hell of a time killing time by talking to each other about mundane things and profound things. Here in Tadhana, all we see is a girl bawling her eyes out in a Rome-to-Manila flight, and their only chance encounter, aside from having met at the airport so boylet can help girlet with her overweight luggage, is seatmates sila and boylet could not care less when girlet was watching the quintessential lovelost-and-love-found-but-sana-ako-na-lang-love-mo-ulit-kasi-tanga-akonung-pinakawalan-kita local romantic drama film One More Chance on her laptop. That's about it. I mean dude, I have had more conversations with strangers in a two-hour trip from Manila to Davao/Dumaguete/wherever Philippines, and this is a Rome to Manila flight ha. Ang dami na dapat nilang napag-usapan, lalo na ang unang crucial thing: na sana nagpakilala muna sila sa isa't isa, karugtong ng pagpapakilala ni boylet sa sarili kay girlet sa airport. I mean, more convos siguro, since tinulungan siya ng boylet, regardless of her sabaw mode from her mega-cryola mode K. ${ }^{6}$ Yes, we want to be cinematic but being cinematic works when we try to be more realistic at first. 
And speaking of being realistic, it really fell flat on its face when meh boylet just went with the flow and accompanied girlet to wherever the hell she felt like going. I mean, sure, realistic pa rin if you ask a "stranger" to eat in a restaurant with you or go to a videoke so you could sing your broken heart out. But to actually have another life form engage you into going on a 500-plus-peso fare ride (one way) going somewhere (so mga lampas $1 \mathrm{k}$ yan if roundtrip) out of Manila is a stretch, especially if there was not enough getting-to-know-you-muna moments between the two of them (see Figure 2). ${ }^{7}$ What Tadhana lacks is what Before Sunrise has developed well: exposition. As in, we get to be exposed to the who/why/what/where/how come stuff of the characters, before they decide to jump to a higher plot point to take the exposition to its more interesting rising action, hopefully to take us to the wonders of the plot's climax and wonder where in the world this climax will take place/happen, and how. Alas, this is where I sort of disengaged with the good concept turned unrealized script, as the directing did not lead us to these seemingly simple but really truly important "smaller" scenes. Are they not as cinematic for one's taste? It should be, since it is in the smaller and simpler scenes that you get the most profound insights, or elicit the most intimate of moments, between characters. Yes, this is realistic, but it could also be cinematic. Think about it. How many films have banked on the simplicity of shots, of a moment, a scene captured not because it has a gazillion things happening at the same time, but only one thing happening at that moment, captured quietly on film, a moment for us to ponder on. Pulso. Pinupulsuhan dapat natin ang panahon, ang eksena, ang detalye ng kuwento. ${ }^{8}$ Sadly, the film wanted to hurry up to the climax of things that it forgot to set up these important pulses that could make the film beat more towards its apex. Sayang.

Sa henerasyong ito ng budget travelers, may pera at panahon ka bang mag-up and go nang basta-basta without thinking of your job (na sa later scenes lang nabanggit), your money (yaman nila to be buying bus tickets just like that ha) or your time? Iangkla ang cinematic sa realistic para mas lumipad siya nang husto. ${ }^{9}$ \#justsaying 


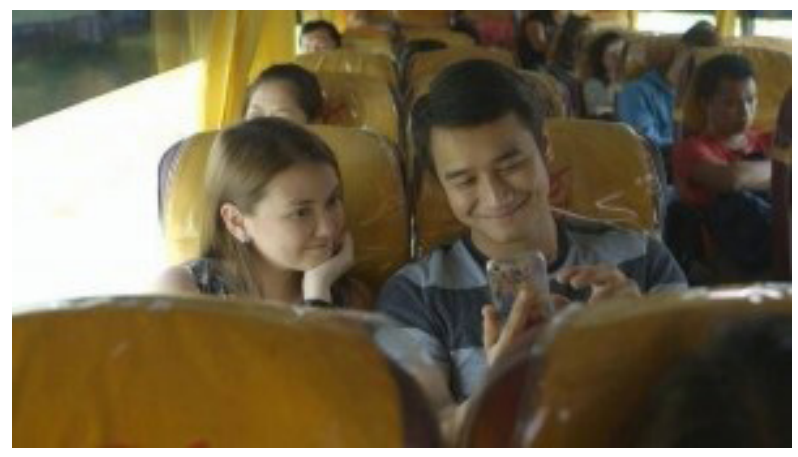

Fig. 2. Anthony and Mace on their bus trip. (That Thing Called Tadhana, Cinema One Originals, Epicmedia, Monoxide Works, and One Dash Zero Cinetools, 2014)

And speaking of not quiet, cinema has its way of speaking to you without letting you hear anything. A good, quietly captured moment could actually speak for itself, and there's no need to drown it with melodramatic musical score. The film also suffers from this drowning from time to time so that I wonder if the filmmakers or the producers are scared of "not hearing" a scene. If so, then it becomes television fare, where the execs seem to be scared of that thing called dead air. In cinema, there is that thing called pregnant silence. Ang daming laman kahit wala kang naririnig, dahil sa ang nakikita mo ay marami nang sinasabi agad. At ang dami niyang feels! You got a great actor na and a great story to boot, so let them speak for themselves sometimes. Sayang these moments, especially when the girlet was just feeling the moment, kunwari 'yung nasa Sagada siya and shouted her frustrations amidst the clouds atop Mt. Kiltepan. ${ }^{10}$ Her shouting on that quiet scenery could have made a great poignant scene. But again, it was drowned by musical score. Heartache needs to be felt lang sometimes, not heard. Let the scene breathe on its own. I hope they keep this in mind next time.

And this is why I titled this review the way I did. Because no matter how we tout that the future of Philippine cinema is already here, the future that we hopefully want to happen is not quite happening now, at least not yet. Not when the mainstream's heavy hand is so obvious in shaping the form of 


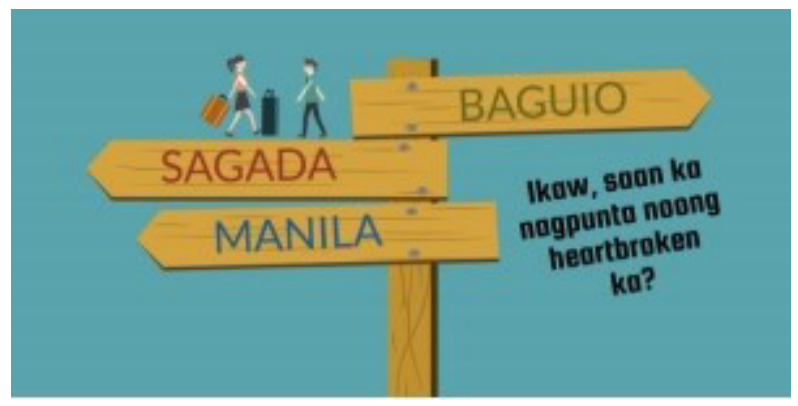

Fig. 3. That Thing Called Tadhana publicity material. (Cinema One Originals, Epicmedia, Monoxide Works, and One Dash Zero Cinetools, 2014)

these future-leading folks, not when these young ones feel like they have to be or mimic their mainstream mentors in order to be taken to the fold. In a way, if this is the objective-to become one with the fold-then this film has already succeeded. But seeing that the future may also want to have a different take on things, then maybe we still have to see what they will come up with next, in order for us to get excited more about how they could revive the future of this art we so love. But yes, this is indeed a great start.

I could see why so many people like this film, the same reason why I like it: its believability. I mean, sino ba naman kasi ang hindi na-heartbroken sa Pilipinas, at may populasyon nga dito na nagtatangkang maglakbay kapag ganito ang moda. And yes, laging ang default ay bundok: Baguio, Sagada ganyan (Fig. 3). Natawa nga ako sa concept na ito, at salamat at may nagtanong nito finally. Puwede rin namang beach ang puntahan, di ba? Bilang archipelago tayo, mas madali 'yun. Pero siguro dahil love could move mountains dapat ang peg, bundok ng tralala ang inaakyat ng Pinoy para doon hanapin ang sagot sa tanong ng lahat ng heartbroken: huwayyyyy or huwaaaay meeeee. And of course, andiyan ang unending love quotes and love songs to make you cry. Pero sana din naman, nailatag ang characterization ni girlet bilang love-quoting girl, kasi iisang quote lang lagi ang kinuquote niya, and it kinda gets tiring teh. Quote pa more, girl. Dami pa riyan. Buklat ka ng Eat Pray Love baka makatulong hane? Or Shakespeare. Yes, these 
are the new things that we want to see in our local films. This believability works. It is just the delivery that lacks a bit and I find wanting. In Tagalog, tinimbang ngunit overweight sa ilang bagay at underweight sa iba. ${ }^{11}$ Yes, we want a new cinematic recipe indeed, and thanks for this really nice bite. But I hope the cinematic commercial cookie cutter gets challenged more next time. Hashtag just saying.

Again, great story. Loved this film because of the good concept. Witty will truly save the world, to quote Tonet's other business, but I also hope someday, witty will be brave enough to break out of the mold, to discover her own. Andiyan na naman, eh. And the audiences are ready for it; long overdue, actually. I guess all I'm saying is: talon pa more! $!^{12}$

Good luck with the next one. Looking forward to it. 


\section{Acknowledgment}

Reprinted with author's permission from the Takilya ni Leaflens blog, February 16, 2015, leaflenstakilya.wordpress.com/2015/02/16/ the-future-is-here-but-the-future-is-not-now/. 


\section{Translations}

1. Am I right, Professor Teodoro Agoncillo?

2. That and your granny had to attend to her love life first hehe, so now you know.

3. ...who undergoes real shitty this-isn't-for-romcom-dammit type of love stories.... Like I've never been so pleased to see a pretty heartbroken girl say Sonofabitch! or Bitch please! with a texture that's even crunchier than Lapid's pork cracklings man, all because her heart is hurting. This is how real people behave when they're heartbroken and it's real painful so you'll really cuss out without any class, finesse, or any respectability in your appearance or personality sometimes when you are brokenhearted dammit your nose runs while you squall and all. Angelica's performance of the brokenhearted Pinay was well-captured here, she really delivers a great performance. Ever since I saw a different side of her as a non-sitcom type of comedian in Here Comes the Bride [directed by Chris Martinez, 2010], gurl is capable of attaining a superior level of performance.

4. ...once the darling of our business unit [at Channel 2] when I was there in my recent past as part of a team conceptualizing teleseryes and helping out in reality shows.... As in he did not seem inspired to shoot, much less to work. But I think this meh mode of his worked to build the character of the meek dude.... But then I wished that once in a while, they managed to infuse enough caffeine in his body, know what I am saying. Or maybe I am just nitpicking. Have more coffee!

5. I felt like some scenes showing the guy's characters were axed, therefore reducing his performance into an expressionless type of guy that ended up not being realistic. Like towards the end, when he mentioned that he mentioned a person taking care of him with Biogesic or something, I was like "So where is that scene?" you know. Weird limbo scenes man.

6. ...now that the love is gone, as that song went somewhere. Not new because we have already seen films where strangers on a train/bus/plane/what-have-you was the setup, and of course my generation - and theirs- had Richard Linklater's Before series as a default setup.... Here in Tadhana, all we see is a girl bawling her eyes out in a Rome-to-Manila flight, and their only chance encounter, aside from having met at the airport so young buck can help young lass with her overweight luggage, is they are seatmates and the guy could not care less when the girl was watching the quintessential love-lost-and-love-found-but-I-wishyou-loved-me-again-because-I-was-stupid-to-let-you-go local romantic drama film One More Chance [directed by Cathy Garcia-Molina, 2007] on her laptop.... There was so much for them to talk about, especially the first crucial thing: that they should have introduced themselves further to each other, after the initial introduction of the guy to the girl at the airport. I mean, more convos I guess, 
since she was assisted by the guy, regardless of her distracted mode from her mega-cry-a-river mode OK.

7. ...going somewhere (so around more than 1,000 pesos if it's a roundtrip) out of Manila is a stretch, especially if there was not enough getting-to-know-you-first moments between the two of them.

8. Pulse. One should first take the pulse of the time, the scene, the details of the narrative.

9. In this generation of budget travelers, would you have the money and time to up and go on a whim without thinking of your job (which were only mentioned in the later scenes), your money (they are loaded to be buying bus tickets just like that ha) or your time? Anchor the cinematic to what is realistic so that the film soars more fully.

10. Too much content even if you do not listen, because what is onscreen already speaks volumes. And it is packed with feels! You got a great actor already and a great story to boot, so let them speak for themselves sometimes. Too bad these moments, especially when the girl was just feeling the moment, as for example when she was in Sagada and shouted her frustrations amidst the clouds atop Mt. Kiltepan.

11. I mean, who has not been heartbroken in the Philippines, and there is a local populace that wishes to get away when they are in that mode. And yes, the mountain's always the default: Baguio, Sagada and so on. I was amused by this concept, and I am glad that someone raised the question finally. They could have gone to a beach too, right? Since the country's an archipelago, that would have been more doable. But maybe because love could move mountains was the required peg, any mountain anywhere is what Pinoys climb so they could find there the answer to everyone who's ever been heartbroken: whyyyyy or whyyyy meeeee. And of course, you have got those unending love quotes and love songs to make you cry. But I also wish as well that the protagonist's characterization as lovequoting girl was better explained, since she kept quoting the same quote, and it kinda gets tiring sis. Quote some more, girl. There are many others. Crack open a copy of Eat Pray Love and it might help dear? Or Shakespeare.... In Tagalog, it was weighed but found overweight in some matters and underweight in others.

12. You have initiated it already, see.... I guess all I'm saying is: take the plunge! 